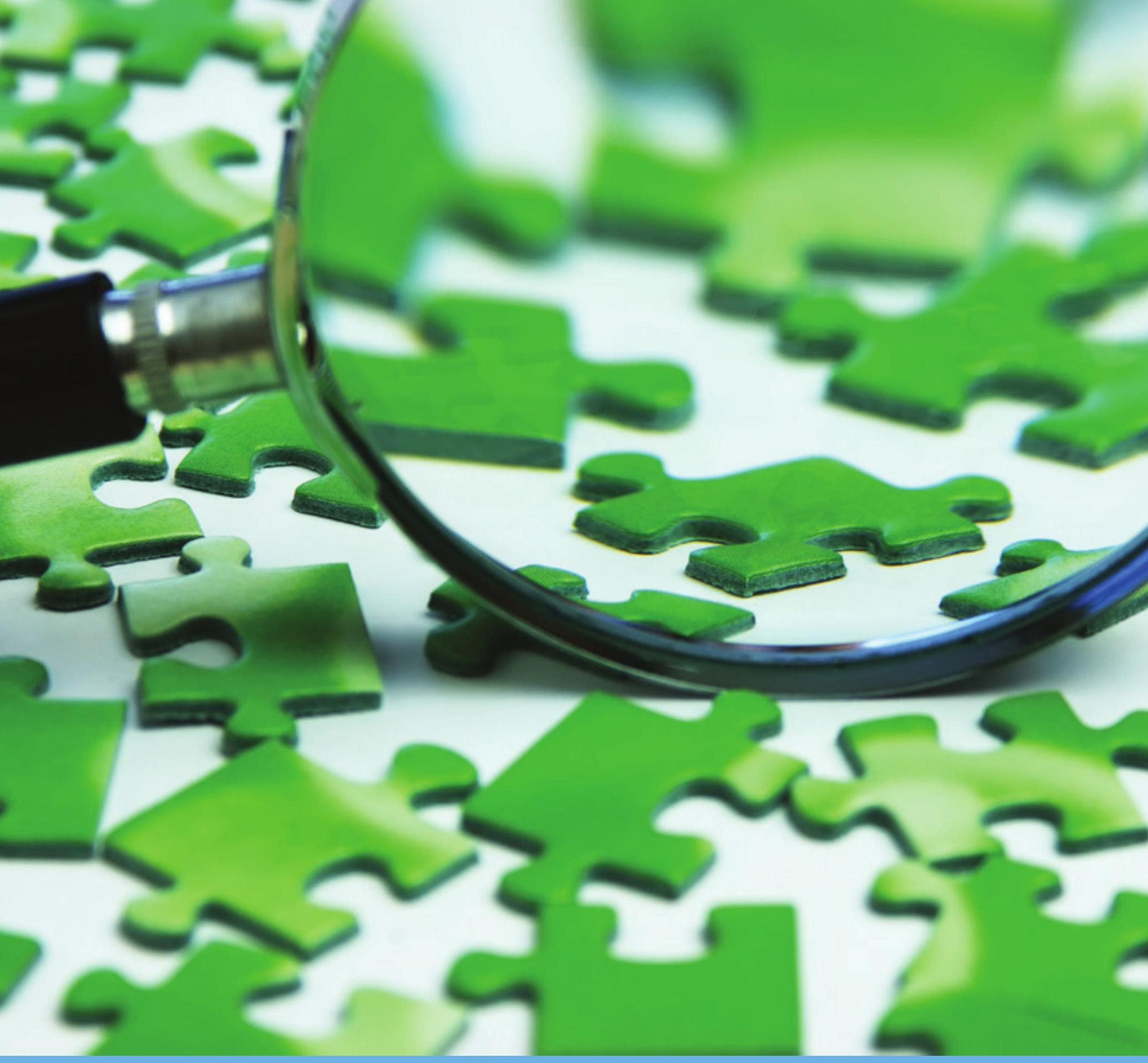

Peer review Nederlandse beschikbaarheid en vraag naar voedsel, veevoer en biomassa voor non-food in 2030 en 2050

Jan Broeze en Wolter Elbersen

WAGENINGEN

UNIVERSITY \& RESEAREH 



\section{Peer review Nederlandse beschikbaarheid en vraag naar voedsel, veevoer en biomassa voor non-food in 2030 en 2050}

Auteurs: Jan Broeze en Wolter Elbersen

Instituut: Wageningen Food \& Biobased Research

Dit onderzoek is uitgevoerd door Wageningen Food \& Biobased Research in opdracht van en gefinancierd door het Ministerie van Landbouw, natuur en voedselkwaliteit (projectnummer 6234139800). 
Versie: definitief

Reviewer: Harriette Bos

Goedgekeurd door: Ben Langelaan

Opdrachtgever: het Ministerie van Landbouw, natuur en voedselkwaliteit

Financier: het Ministerie van Landbouw, natuur en voedselkwaliteit

Dit rapport is gratis te downloaden op https://doi.org/10.18174/466574/ of op www.wur.nl/wfbr (onder publicaties).

(C) 2018 Wageningen Food \& Biobased Research, instituut binnen de rechtspersoon Stichting Wageningen Research.

Het is de opdrachtgever toegestaan dit rapport integraal openbaar te maken en ter inzage te geven aan derden. Zonder voorafgaande schriftelijke toestemming van Wageningen Food \& Biobased Research is het niet toegestaan:

a. dit door Wageningen Food \& Biobased Research uitgebrachte rapport gedeeltelijk te publiceren of op andere wijze gedeeltelijk openbaar te maken;

b. dit door Wageningen Food \& Biobased Research uitgebrachte rapport, c.q. de naam van het rapport of Wageningen Food \& Biobased Research, geheel of gedeeltelijk te doen gebruiken ten behoeve van het instellen van claims, voor het voeren van gerechtelijke procedures, voor reclame of antireclame en ten behoeve van werving in meer algemene zin;

c. de naam van Wageningen Food \& Biobased Research te gebruiken in andere zin dan als auteur van dit rapport.

Postbus 17, 6700 AA Wageningen, T 03174800 84, E info.wfbr@wur.nl, www.wur.nl/wfbr. Wageningen Food \& Biobased Research is onderdeel van Wageningen University \& Research.

Alle rechten voorbehouden. Niets uit deze uitgave mag worden verveelvoudigd, opgeslagen in een geautomatiseerd gegevensbestand of openbaar gemaakt in enige vorm of op enige wijze, hetzij elektronisch, hetzij mechanisch, door fotokopieën, opnamen of enige andere manier, zonder voorafgaande schriftelijke toestemming van de uitgever. De uitgever aanvaardt geen aansprakelijkheid voor eventuele fouten of onvolkomenheden. 


\section{Inhoud}

2 Beschikbaarheid van biomassa voor voedsel, veevoeders en biobased 6

2.1 Mondiale productie: biomassabalansen in het huidige systeem 6

2.2 Mondiaal productiepotentieel voor 2030 en $2050 \quad 7$

2.2.1 Schatting van productie van voedsel en veevoeders in 2030 en $2050 \quad 7$

2.2.2 Schattingen van mondiaal beschikbare biomassa voor non-food domeinen $\quad 7$

2.3 Huidige Nederlandse productie/beschikbaarheid $\quad 8$

2.3.1 Productie van voedselproducten $\quad 8$

2.3.2 Productie van veevoeders 9

2.3.3 Productie van non-food biomassa in Nederland 9

2.4 Verwachte Nederlandse productie in 2030 en $2050 \quad 9$

3 Vraag naar biomassa voor voedsel, veevoeders en biobased 10

$\begin{array}{lll}3.1 & \text { Nederlandse en mondiale voedselvraag } & 10\end{array}$

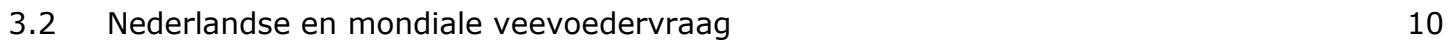

3.3 Verwachte mondiale vraag naar biomassa voor biobased toepassingen 11

3.4 Verwachte Nederlandse vraag naar biomassa voor biobased toepassingen 12

4 Samenvattend overzicht en concluderende opmerkingen 13

Appendix A. Projection of food consumption for 2030 and 2050 according to FAO 15

$\begin{array}{lr}\text { Appendix B. Diepgaandere analyse voedselconsumptie } & 16\end{array}$

Appendix C. Scenario's voor ontwikkeling Nederlandse voedselvraag 19

$\begin{array}{lr}\text { Appendix D. Analyse veevoedervraag } & \mathbf{2 1}\end{array}$

Appendix E. Huidige vraag naar biomassa voor non-food in Nederland 23

Appendix F. Potentieel van non-food biomassa productie in Nederland 25

Appendix G. Review/suggesties bij Visiedocument Biomassa $2030 \quad 26$ 


\section{$1 \quad$ Inleiding}

Het Rijksbrede programma Circulaire Economie richt zich op de transitie naar een circulaire economie, te realiseren voor 2050. Daartoe zijn transitieteams ingesteld die in het najaar van 2017 transitieagenda's gaan opleveren. Vanuit het transitieteam biomassa en voedsel is ter onderbouwing van haar transitie-agenda behoefte aan een peer review naar de Nederlandse behoefte en beschikbaarheid van biomassa in 2030 en 2050.

In Biomassa $2030^{1}$ is in 2015 een visie op de verwachte ontwikkelingen in biomassa-aanbod en behoefte voor energie, brandstoffen en chemie/materialen gepresenteerd. Vanuit nieuwste inzichten, alsmede visie op hoe theoretisch beschikbare biomassa daadwerkelijk praktisch beschikbaar gemaakt kan worden, wordt in dit rapport een peer review van Biomassa 2030 gepresenteerd.

Daarnaast wordt in dit rapport, anders dan in Biomassa 2030, ook vraag en beschikbaarheid van voedsel en veevoer meegenomen. In Biomassa 2030 zijn geen verwachte ontwikkelingen meegenomen van productie en vraag naar voedsel en veevoeder. Door een visie ten aanzien van voedsel en veevoeder te integreren wordt het inzicht in toekomstige behoeftes gecompleteerd en worden verhoudingen in de verschillende behoeftes duidelijker. Bovendien kunnen vanuit dat inzicht praktische ontwikkelingsroutes worden geformuleerd die op basis van bestaande (keten)oplossingen binnen het voedselsysteem biobased behoeftes invullen: benut mogelijke synergie tussen voedsel- en biobased systemen (co-productie en technische innovaties).

Het huidige voedselsysteem focust primair op voedsel en veevoeders. "Biobased" put deels uit 'eigen' grondstoffen (bosbouw), zetmeelgewassen en steeds meer reststromen. Bij toenemende behoefte vanuit biobased ontstaan nieuwe kansen vanuit reststromen en gewassen van voedsel- en veevoederketens. Verknoping van de ketens biedt kansen op synergie waardoor biobased ontwikkelingen versneld worden.

In de visie Biomassa 2030 zijn verwachtingen t.a.v. vraag naar biomassa voor energie, biobrandstoffen, chemie en materialen afgeleid uit beleidsdoelen (o.a. 27\% hernieuwbare energie), de Nationale Energie Verkenning (NEV 2015), Duurzame brandstofvisie met LEF ${ }^{2}$, verwachtingen vanuit de branchevereniging van de chemische industrie in Nederland (VNCI) en strategische doelen van het Europese Biobased Industries Consortium (BIC). De totale vraag voor 2030 wordt aldus geschat op 435-596PJ, dat komt neer op ongeveer 25-35Mton droge stof.

Verwachte beschikbaarheid is afgeleid van de mondiale productie van biomassa, op basis van toedeling per capita resp. naar aandeel in primair energieverbruik. Mede afhankelijk van de vraag in welke mate de geproduceerde biomassa daadwerkelijk beschikbaar gemaakt kan worden, wordt de beschikbaarheid van biomassa voor Nederland geschat op 115-753 PJ (7-45Mton droge stof).

Ten aanzien van voedsel en veevoer vraag en aanbod zijn ook visie- en beleidsstukken beschikbaar, maar die zijn primair gericht op kortere termijnontwikkelingen en kwalitatieve veranderingen en minder op kwantitatieve verwachtingen.

\footnotetext{
${ }^{1}$ Biomassa 2030, Strategische visie voor de inzet van biomassa op weg naar 2030, Ministerie van Economische Zaken, 2015.

2 Een duurzame brandstofvisie met LEF, Ministerie van Infrastructuur en Milieu, 2014.
} 
$W_{R R}^{3}$ schetst diverse ontwikkelingen van met grote invloed op het voedselsysteem: industrialisering van de landbouw, globalisering van de voedselvoorziening, toegenomen belang van niet-agrarische spelers, verandering van eetpatronen en tegenbewegingen (biologisch, lokaal/regionaal, bewust consumeren). Nederland is een knooppunt in de Noordwest-Europese markt. Genoemde mondiale uitdagingen omvatten ecologische problemen en volksgezondheid. Als reactie hierop heeft het Nederlands Kabinet een Voedselagenda voor veilig, gezond en duurzaam voedse $/^{4}$ opgesteld, waarin aangekondigd dat ze haar beleid op genoemde onderwerpen wil versterken. Op basis van deze agenda heeft het kabinet op nationaal niveau diverse activiteiten ${ }^{5}$ ingezet op het vlak van bewustzijn en gezondheid van voedsel en verduurzaming van productie.

De thema's voedselzekerheid en klimaat worden vooral in internationale initiatieven geadresseerd. Ten aanzien van voedselzekerheid richt het kabinet ${ }^{6}$ zich op duurzame ontwikkeling van de agrarische sector en verduurzaming van voedselsystemen door toepassing van efficiënte, zorgvuldige en klimaatslimme landbouwpraktijken en verduurzaming van consumptiepatronen (minder eiwitrijke voedingspatronen in de ontwikkel(en)de wereld en het terugbrengen van voedselverspilling). Een kwantitatief uitgewerkte visie op vraag een aanbod van voedsel en veevoeder voor de lange termijn, zoals wel beschikbaar voor biobased, ontbreekt echter. Om een meer integrale visie te vormen wordt daarom in dit rapport een aanzet tot een visie voor voedsel en veevoeders geformuleerd.

Het agro-food-biobased-systeem heeft verschillende complicerende facetten die een recht-toe-rechtaan analyse in de weg staan.

Grote hoeveelheden gewassen worden bij raffinage gescheiden in componenten voor verschillende toepassingsdomeinen (voedsel, veevoeder en/of biobased). Die gewassen kunnen dan niet $100 \%$ gealloceerd worden aan één toepassingsdomein.

De Nederlandse vraag en beschikbaarheid zijn via het internationale handelsnetwerk intensief verweven met de internationale vraag en productie. Door het Nederlandse agri-food complex wordt veel toegevoegde waarde gecreëerd, onder andere in de vorm van dierlijke productie, deels op basis van geïmporteerde veevoeders en componenten. De 'Nederlandse vraag' is daarom niet in een eenduidig heldere tabel te grijpen.

Tenslotte is de (verwachte) allocatie van de wereldwijde productie voor Nederland een grote onbekende. Enkele voor de hand liggende opties: op basis van binnenlandse teelt, naar rato van het aantal inwoners of naar rato van bbp (zoals in het Visiedocument Biomassa 2030).

Het in detail uitwerken van deze complexiteit overstijgt de ambitie van dit rapport. Daarom wordt in dit rapport vooral verder gebouwd op basis van cijfers en aannames uit andere publicaties.

Opmerking: De studie is primair gericht op de productiepotentie van, en vraag aan het landbouwsysteem. Reststromen uit de maatschappij (inclusief 'afval' en recyclebare producten) vullen nu al een deels de 'biobased' vraag in. Deze zijn - omwille van een consistent beeld - zoveel mogelijk weggelaten uit zowel vraag- als aanbodcijfers. Bijproducten uit teelt en verwerking zijn wel meegenomen.

In het volgende hoofdstuk wordt in eerste instantie de mondiale productie (en productiepotentieel) uitgewerkt, alvorens de potentiële beschikbaarheid voor Nederland mede op basis daarvan wordt bepaald (o.a. op basis van allocatie van wereldwijd potentieel).

Vervolgens wordt in hoofdstuk 3 de verwachte vraagontwikkeling verder uitgewerkt, zowel de mondiale als de Nederlandse.

In hoofdstuk 4 worden vervolgens de verwachte vraag- en aanbodontwikkeling met elkaar vergeleken. Met het oog op leesbaarheid zijn diverse onderbouwende analyses in bijlages geplaats. Voor zover beschikbaar zijn meerdere (onafhankelijke) informatiebronnen gezocht, en/of zijn aannames gemaakt in de betreffende bronnen kritisch tegen het licht gehouden.

Tenslotte is een reflectie op het Visiedocument in de laatste bijlage geplaatst.

\footnotetext{
3 WRR: Naar een voedselbeleid, Amsterdam University Press, Amsterdam 2014.

4 Tweede Kamer 2015-2016, 31532, nr. 156.

${ }^{5}$ Voortgang Voedselagenda voor veilig, gezond en duurzaam voedsel, Tweede Kamer 2016-2017, 31532 , nr. 174.

${ }^{6}$ beleidsbrief 'Nederlandse inzet voor wereldwijde voedselzekerheid' (Kamerstuk 33625, nr. 147)
} 


\section{$2 \quad$ Beschikbaarheid van biomassa voor voedsel, veevoeders en biobased}

Zoals beargumenteerd in de visie Biomassa 2030 wordt verwacht dat een aanzienlijk deel van Nederlandse vraag naar biomassa voor energie en materialen zal worden ingevuld op basis van import. Dat is vergelijkbaar met de huidige situatie voor veevoeders. Vanwege de onderlinge relatie tussen voedselketens, dierlijke producten en veevoeders en het biobased domein is een integraal beeld van biomassabeschikbaarheid voor voedsel, veevoeders en biobased, voor Nederland in de mondiale context essentieel. Daarom wordt in dit hoofdstuk zowel het mondiale productiepotentieel, de Nederlandse productie en mogelijke allocatie van de mondiale productie voor Nederland in kaart gebracht.

\subsection{Mondiale productie: biomassabalansen in het huidige systeem}

Op basis van informatie uit diverse publicaties wordt in Tabel 1 en Tabel 2 een globaal overzicht van biomassabalansen in het mondiale agri-food systeem weergegeven. Daarbij zijn ook de stromen die momenteel niet worden geëxploiteerd opgenomen. Deze zouden eventueel beschikbaar gemaakt kunnen worden voor nieuwe (biobased) toepassingen.

Tabel 1. Schattingen van mondiale biomassaproductie in Gton droge stof per jaar voor verschillende toepassingsgebieden t.b.v. zowel voedsel, veevoeder als biobased domeinen ${ }^{7}$

\begin{tabular}{|c|c|c|c|c|}
\hline Bron & Areaal (Gha) & Product & Huidige toepassing & Hoeveelheid (Gton/jr) \\
\hline \multirow[t]{3}{*}{ Bosbouw } & 4 & Hout & Papier, textiel en andere toepassingen & 1,0 (PBL, 2014; Wirsenius, 2007) \\
\hline & & & Energie & $2,7(\mathrm{PBL}, 2014)$ \\
\hline & & Kapresten & (onbenut)/bodem org. Stof & 1,2 (Krausmann et al., 2008) \\
\hline \multirow[t]{2}{*}{ Gras } & 3,3 & Gras & begrazing/veevoeder & $3,7\left(N_{0 V A}, 2015\right)$ \\
\hline & & Blijft achter & (onbenut)/bodem org. stof & 2,5 (schatting) \\
\hline \multirow[t]{4}{*}{ Gewassen } & 1,5 & Hoofdproduct & voedsel(ingrediënt) & 1,7 (NOVA, 2015) \\
\hline & & & Veevoeder & 2,0 (NOVA, 2015) \\
\hline & & & niet-voedsel & $0,1(\mathrm{NOVA}, 2015)$ \\
\hline & & Gewasrest & Veevoeder & 0,7 (NOVA, 2015) \\
\hline
\end{tabular}

${ }^{7}$ Bronnen voor hoeveelheden in Tabel 1 en Tabel 2:

FAOSTAT: http://www.fao.org/faostat/en/\#data (data retrieved 2016 and 2017)

IEA (2015): Key World Energy Statistics, OECE/IEA.

Krausmann, F, K-H Erb, S Gingrich, C Lauk \& H Haberl (2008): Global patterns of socioeconomic biomass flows in the year 2000: A comprehensive assessment of supply, consumption and constraints, Ecological Economics 65, pp. 471-487.

NOVA (2015): S. Piotrowski, M. Carus \& R. Essel: Global bioeconomy in the conflict between biomass supply and demand, Nova paper \#7 on bio-based economy 2015-09.

PBL (2014): G.J. van den Born, J.G. van Minnen, J.G.J. Olivier \& J.P.M. Ros: Integrated analysis of global biomass flows in search of the sustainable potential for bioenergy production, PBL report 1509, PBL, The Netherlands.

Potter, P., N. Ramankutty, E.M. Bennett \& S.D. Donner (2010): Characterizing the spatial patterns of global fertilizer application and manure production, Earth Interactions, Vol. 14, pp. 1-22.

WBA (2013): Biogas - An important renewable energy source, WBA fact sheet, World Bioenergy Association, Sweden.

Wirsenius, S. (2007): Global use of agricultural biomass for food and non-food purposes: current situation and future outlook, Proceedings of Traditional Grains for Low Environmental Impact and Good Health. 


\begin{tabular}{|c|c|c|}
\hline & niet-voedsel & 0,4 (NOVA, 2015) \\
\hline & Energie & 0,3 (NOVA, 2015) \\
\hline Blijft achter & Verbranden & 2,4 (Krausmann et al., 2008) \\
\hline & blijft achter, bovengronds & 1,4 (Krausmann et al., 2008) \\
\hline & blijft achter, ondergronds & 1,8 (Krausmann et al., 2008) \\
\hline
\end{tabular}

Tabel 2. Stromen in de na-oogst keten.

\begin{tabular}{|c|c|c|c|}
\hline $\begin{array}{l}\text { Segment in "na-oogst } \\
\text { keten" }\end{array}$ & Product & Huidige toepassing & Hoeveelheid (Gton/jr) \\
\hline \multirow[t]{3}{*}{ Voedselketen ${ }^{8}$} & Hoofdproduct & Voedsel en ingrediënten & $\begin{array}{l}\text { 1,5 (geschatte voedselvraag op basis van } \\
\text { kcal, FAOSTAT data) }\end{array}$ \\
\hline & Bijproducten & $\begin{array}{l}\text { Voornamelijk } \\
\text { veevoeders }\end{array}$ & 0,2 (PBL, 2014) \\
\hline & Verliezen & $\begin{array}{l}\text { Afval (o.a. } \\
\text { compostering) }\end{array}$ & $\begin{array}{l}0,2 \text { (schatting op basis van food waste } \\
\text { publicaties) }\end{array}$ \\
\hline \multirow[t]{3}{*}{ Veehouderij } & Vlees & $\begin{array}{l}\text { Voedselketen (zie } \\
\text { hierboven) }\end{array}$ & 0,2 (FAOSTAT) \\
\hline & Mest & Bemesting & $\begin{array}{l}3,6 \text { (geschat op basis van mondiale } \mathrm{N} \text { en } \mathrm{P} \\
\text { balans studies) }\end{array}$ \\
\hline & & Biogas & $0,03(\mathrm{WBA}, 2013)$ \\
\hline Consument & $\begin{array}{l}\text { Verspilling / } \\
\text { afval }\end{array}$ & $\begin{array}{l}\text { Afval (o.a. } \\
\text { compostering) }\end{array}$ & $\begin{array}{c}0,3 \text { (schatting op basis van food waste } \\
\text { publicaties) }\end{array}$ \\
\hline
\end{tabular}

\subsection{Mondiaal productiepotentieel voor 2030 en 2050}

\subsubsection{Schatting van productie van voedsel en veevoeders in 2030 en 2050}

FAO verwacht wereldwijd voor agrarische productie tot 2030 een gemiddelde jaarlijkse groei van 1,3\% en tussen 2030 en 2050 gemiddeld 0,8\% per jaar. Uitgaande van huidige productietotalen (geleid uit Tabel 1 en Tabel 2, overeenkomend met getallen van FAO), zijn productiecijfers voor 2030 en 2050 door extrapolatie met deze groeicijfers geschat (Tabel 3).

Tabel 3. Geschatte mondiale productie van voedsel en veevoeders (Gton/jr).

\begin{tabular}{lccc}
\hline Categorie & Huidige productie & $\mathbf{2 0 3 0}$ & $\mathbf{2 0 5 0}$ \\
\hline Voedselproducten & 1,5 & 1,8 & 2,1 \\
\hline Veevoeders & 6,6 & 7,8 & 9,2 \\
\hline
\end{tabular}

\subsubsection{Schattingen van mondiaal beschikbare biomassa voor non-food domeinen}

\section{Biomassabeschikbaarheid volgens het Visiedocument Biomassa 2030}

Het Visiedocument Biomassa 2030 voorziet voor niet-voedseltoepassingen een mondiaal biomassaaanbod van 50-150 EJ (dat komt overeen met 3 tot 9 Gton droge stof) ${ }^{9}$. De grote spreiding hangt samen met o.a. percentages van de aanwezige biomassa die daadwerkelijk beschikbaar gemaakt wordt en de mate waarin landoppervlak aangewend wordt voor biomassateelt.

${ }^{8}$ Omvat versketen en voedselverwerking

${ }^{9}$ Het Visiedocument baseert deze cijfers op PBL 2013: Biomassa: wensen en grenzen, die vervolgens weer doorverwijst naar Dornburg, V. et al. (2008): Biomass Assessment. Assessment of global biomass potentials and their links to food, water, biodiversity, energy demand and economy. Dat rapport schat productiepotentieel op een groot aantal wetenschappelijke publicaties. Deze gaan alle uit van betere benutting van allerlei rest- en nevenstromen, gecombineerd met biomassateelt op 'surplus agricultural land'. 


\section{Biomassabeschikbaarheid volgens andere informatiebronnen}

Een gedetailleerder inzicht in biomassabeschikbaarheid kan worden afgeleid uit Tabel 1 en Tabel 2: zowel reststromen uit teelten als bijproducten en verliezen in na-oogst ketens voor voedsel en diervoeders en in dierlijke productie.

Theoretisch beschikbaar voor niet-voedseltoepassingen zijn alle producten uit de bosbouw, nietvoedselproducten uit gewassen, hetgeen achter blijft op het veld uit gras en gewassen, reststromen uit voedselketens en dierlijke mest: 13,5 Gton. Daadwerkelijke beschikbaarheid van deze biomassastromen zal echter beperkt blijven met het oog op praktische rendabele winbaarheid en huidige functie (zoals bodemgezondheid).

Let op: 'alternatieve' mogelijke bronnen, zoals winning uit natuurgebieden, aquatische teelt en grootschalige biomassateelt (dat een groot aandeel vormt in de geschetste potenties volgens het merendeel van de biomassastudies) zijn niet meegenomen in deze schatting. Ook zijn - om eerder genoemde redenen - gerecycleerde en afvalstromen - niet meegeteld.

\subsection{Huidige Nederlandse productie/beschikbaarheid}

\subsubsection{Productie van voedselproducten}

Tabel 4 geeft een globale balans voor Nederlandse voedselgewassen en dierlijke producten. Totale jaarlijkse productie wordt op basis hiervan geschat op 26Mton. Uitgaande van drogestofgehaltes volgens de NEVO tabel voor enkele representatieve producten per categorie, en exclusief granen omdat deze in NL vooral voor niet-voedsel toepassingen worden geteeld in Nederland, komt de totale Nederlandse productie op 4 tot 5 Mton drogestof voedselproducten per jaar.

Tabel 4. Import, productie, export en consumptie van voedselgewassen in Nederland (kton/jaar, nat) voor $2009^{10}$

\begin{tabular}{|c|c|c|c|c|}
\hline & Import & Productie & Export & Consumptie \\
\hline \multicolumn{5}{|l|}{ Zuivel } \\
\hline Zuivel & 1824 & 11791 & 2090 & \\
\hline w.v. kaas & 187 & 712 & 549 & 354 \\
\hline Rundvlees & 337 & 182 & 415 & \\
\hline Rundvlees verwerkt & 19 & & 11 & \\
\hline Pluimveevlees & 374 & 726 & 787 & \\
\hline varkensvlees & 249 & 1786 & 848 & \\
\hline Varkensvlees verwerkt & 19 & & 12 & \\
\hline \multicolumn{5}{|l|}{ Vis } \\
\hline Vis & 349 & 351 & 396 & \\
\hline Vis verwerkt & 263 & & 197 & 370 \\
\hline \multicolumn{5}{|l|}{ Groente } \\
\hline Fruit verwerkt & 1673 & & 1460 & \\
\hline \multicolumn{5}{|l|}{ Koolhydraten } \\
\hline Consumptieaardappelen & 697 & 3647 & 940 & 386 \\
\hline Consumptieaardappelen verwerkt & 403 & & 1630 & \\
\hline $\operatorname{graan}^{11}$ & 11084 & 1994 & 1508 & \\
\hline Graan verwerkt & 1559 & & 1566 & 2248 \\
\hline suiker & 132 & 990 & 265 & 458 \\
\hline Suiker 'rest' en verwerkt & 378 & & 244 & \\
\hline TOTAAL & 14253 & 990 & 6153 & \\
\hline
\end{tabular}

10 Uit: A. van der Knijff, J. Bolhuis, M. van Galen en R. Beukers: Verduurzaming voedselproductie. Inzicht in productie, import, export en consumptie van voedsel, LEI Wageningen UR, LEI-nota 11-085, 2011.

Deze publicatie geeft licht verschillende cijfers voor import en export in hoofdstuk 2 en hoofdstuk 3 . De cijfers in hoofdstuk 2 liggen in de buurt van cijfers in FAOSTAT, daarom zijn die hier overgenomen.

11 Granen: overgrote deel van de Nederlandse productie voor niet-voedsel. 


\subsubsection{Productie van veevoeders}

In Nederland worden vooral ruwvoeders (vooral gras), mengvoeders, veevoedergewassen en vochtrijke veevoeders geproduceerd. De vochtrijke veevoeders zijn bijproducten uit agro-food processing. De totale productie wordt geschat op 23Mton (droge stof) per jaar. Hierin zijn bijproducten wel meegerekend, ruim 50\% van de mengvoedergrondstoffen. Aangezien primaire grondstoffen in mengvoeders nagenoeg volledig uit import wordt betrokken wordt de overige $50 \%$ niet toegerekend aan Nederlandse productie. Onderliggende cijfers zijn weergegeven in Appendix D.

Tabel 5. Geschatte huidige productie van veevoeders in Nederland uit binnenlandse teelt en bijproducten.

\begin{tabular}{lc}
\hline Categorie & Productie in Nederland (Mton droge stof per jaar) \\
\hline Mengvoeders (aandeel bijproducten) & 6 \\
\hline Ruwvoeders & 11 \\
\hline Veevoedergewassen & 5 \\
\hline Vochtrijke veevoeders & 1 \\
\hline TOTAAL & 23 \\
\hline
\end{tabular}

\subsubsection{Productie van non-food biomassa in Nederland}

De huidige Nederlandse biomassa-balans voor non-food (energie, brandstoffen, materialen en chemicaliën) is door CE Delft ${ }^{12}$ gedetailleerd in kaart gebracht. Daaruit blijkt veruit het grootste deel van de biomassa wordt betrokken uit gerecycleerde, reststromen en import, en slechts een kleine hoeveelheid binnenlandse productie ( 0,2 à 0,3 Mton) en bijproducten ( 0,2 Mton) betreft.

\subsection{Verwachte Nederlandse productie in 2030 en 2050}

FAO verwacht voor ontwikkelde landen voor agrarische productie tot 2030 een jaarlijkse groei van 0,7\% en tussen 2030 en 2050 gemiddeld 0,3\% per jaar. Op basis daarvan zijn schattingen voor Nederlandse voedsel- en veevoederproductie in 2030 en 2050 weergegeven in Tabel 6.

Tabel 6. Verwachte ontwikkeling van productie van voedsel en veevoeders uit de Nederlandse landbouw op basis van FAO groeivoorspellingen.

\begin{tabular}{lccc}
\hline Categorie & Huidige productie & $\mathbf{2 0 3 0}$ & $\mathbf{2 0 5 0}$ \\
\hline Voedselproducten & 4-5Mton & $4,4-5,5 \mathrm{Mton}$ & $4,7-5,8 \mathrm{Mton}$ \\
\hline Veevoeders & $23 \mathrm{Mton}$ & $25 \mathrm{Mton}$ & $27 \mathrm{Mton}$ \\
\hline
\end{tabular}

Ten aanzien van non-food is en blijft het potentieel voor primaire productie door de Nederlandse landbouw gering.

PBL (2013) schat het biomassa-potentieel op maximaal 200PJ, dat staat gelijk aan ongeveer $12 \mathrm{Mton}$ droge stof, maar geeft ook aan dat vooral gebaseerd is op rest- en afvalstromen, biomassa uit parken, natuurbeheer, etc.. Het productiepotentieel voor biobased (zoals wilgen en suikerbuiten) "levert naar verwachting slechts een bescheiden bijdrage".

In bovenstaande is geen rekening gehouden met eventuele grote verschuivingen tussen de categorieën voedsel/veevoeders/biobased.

\footnotetext{
12 Van Lieshout, M. \& T. Scholten (2017): Sustainable biomass and bioenergy in the Netherlands. Report 2016, CE Delft publicatie 17.3J93.41, Delft.
} 


\section{Vraag naar biomassa voor voedsel, veevoeders en biobased}

\subsection{Nederlandse en mondiale voedselvraag}

De voedselvraag - die naast consumptie ook verliezen en andere inefficiënties in de keten omvat kan worden afgeleid uit voedsel-supply cijfers van FAO.

Volgens de berekening in Appendix A bedraagt dat huidige gemiddelde totale voedselvraag per Nederlander 716 gram droge stof per dag, dat is $262 \mathrm{~kg}$ per jaar. Bij de huidige Nederlandse bevolkingsomvang (17 miljoen inwoners) bedraagt de totale voedselvraag dus $\mathbf{4 , 4 5}$ Mton droge stof per jaar.

Bij gelijkblijvende bevolkingsomvang zou deze vraag ten gevolge van oplopende voedselvraag per capita oplopen naar 4.6 en 4.7 Mton droge stof in 2030 resp. 2050. Voor verschillende alternatieve scenario's (inclusief demografische ontwikkeling, zie Appendix C) varieert de verwachte Nederlandse voedselvraag voor 2050 tussen 4,5 en 5,2 Mton droge stof.

Op soortgelijke wijze zijn ook de mondiale voedselvraag voor nu en 2050 geschat: 1.5 Gton in 2010, oplopend naar 2,4 Gton in 2050 (waarbij rekening is gehouden met zowel toenemende gemiddelde consumptie als oplopende populatie).

\subsection{Nederlandse en mondiale veevoedervraag}

De Nederlandse veehouderij is behoorlijk onafhankelijk van de interne voedselmarkt: een groot deel van de producten wordt geëxporteerd, en een aanzienlijk deel van de veevoedergrondstoffen wordt geïmporteerd. Daarom zal de omvang van de veehouderij en de benodigde veevoeders niet direct gecorreleerd zijn aan de voedselvraag naar dierlijke producten.

Een gedetailleerde analyse naar de huidige en verwachte Nederlandse veevoedervraag is weergegeven in Appendix D. Resultaten zijn kort samengevat in Tabel 7.

Tabel 7. Samenvatting huidige en verwachte veevoedervraag in Nederland (Mton droge stof

per jaar).

\begin{tabular}{lcc}
\hline Categorie & Huidige vraag & $\mathbf{2 0 3 0}$ \\
\hline Mengvoeders & 13 & $\mathbf{2 0 5 0}$ \\
\hline Gras & 11 & \\
\hline Overige veevoedergewassen & 5 & \\
\hline Vochtrijke veevoeders & 1 & $27-31$ \\
\hline TOTAAL & 28 & $25-29$ \\
\hline
\end{tabular}

De huidige mondiale veevoedervraag wordt - op basis van Tabel 1 en Tabel 2 - geschat op 6,6Gton droge stof per jaar. Tot 2050 wordt een toename in veevoedervraag verwacht van ongeveer $25 \%{ }^{13}$, zodat de totale veevoedervraag in 2050 wordt geschat op 8,3Gton droge stof per jaar.

\footnotetext{
13 FAO (2012): World Agriculture towards 2030/2050. The 2012 Revision, ESA Working Papers No. 12-03, Agricultural Development Economics Division, Food and Agriculture Organization of the United Nations.
} 


\subsection{Verwachte mondiale vraag naar biomassa voor biobased toepassingen}

De vraag naar biomassa buiten het food en feed domein kan globaal worden opgesplitst naar vezels/materialen, chemicaliën/plastics en energie/brandstoffen.

\section{Energie/brandstoffen}

IEA schat huidige productie van bioenergie op ongeveer 50PJ (3Gton droge stof biomassa), met een toename in totale vraag voor bioenergie en biobrandstoffen tot 100 resp. 60PJ in 2050 (totaal 9 à 10Gton droge stof biomassa), zie Figuur 1.

\section{Comparison of primary bioenergy demand in this roadmap and global technical bioenergy potential estimate in 2050}

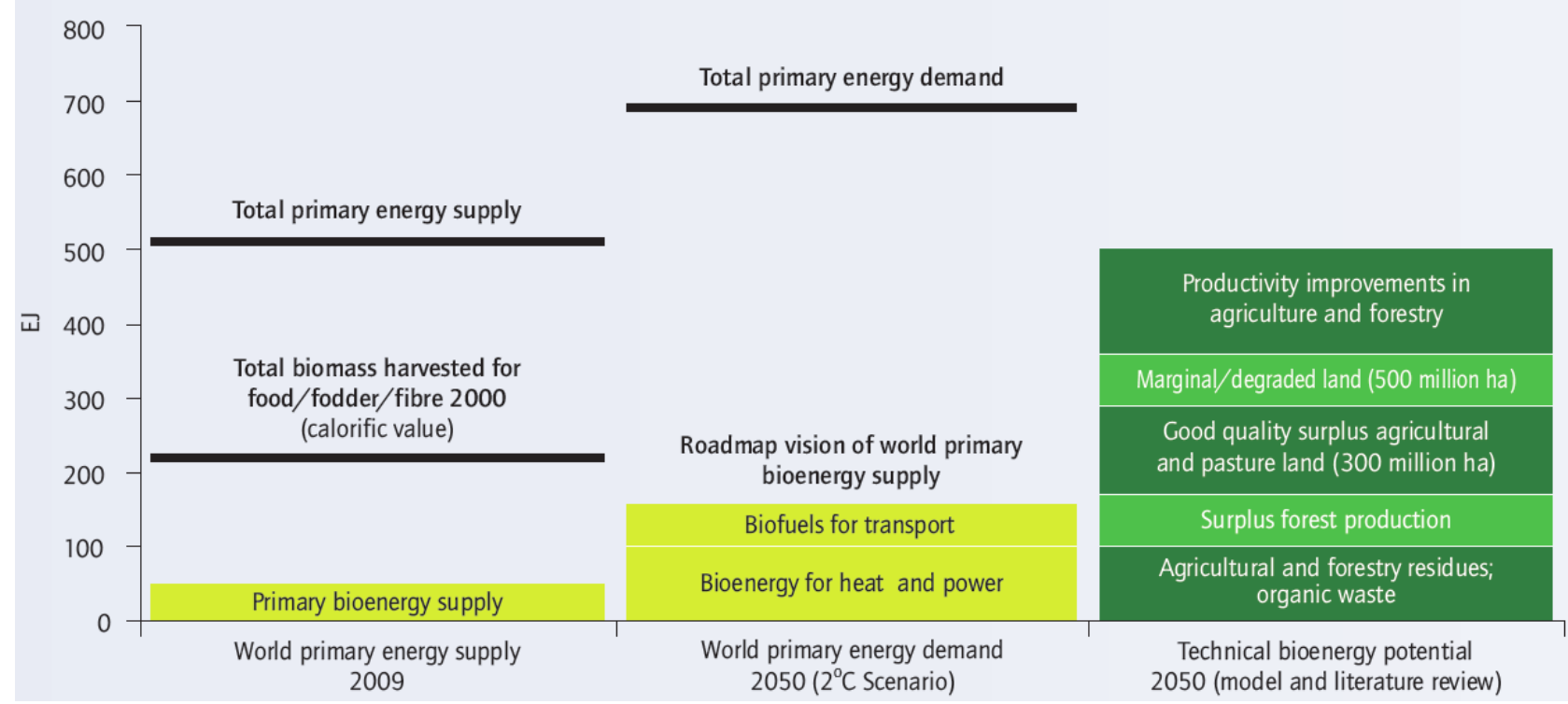

Figuur 1. Vergelijking van primaire energie-behoefte volgens de IEA roadmap en geschatte biomassa-potentieel in $2050^{14}$.

\section{Chemicaliën/plastics}

Huidige biomassa-input is minimaal ten opzichte van de andere domeinen. Indien alle fossiele bronnen vervangen zouden worden door biobased, zou in 2050 ongeveer 1,5Gton biomassa (droge stof) nodig zijn. De daadwerkelijke vraag in 2050 zal ergens in het midden liggen; hier wordt uitgegaan van 0,5 Gton.

\section{Vezels/materialen}

Vraag naar vezels en materialen is o.a. gericht op papier, textiel, en bouw- en constructiematerialen (vooral hout). Huidige mondiale vraag is ongeveer $1 \mathrm{Gton}$ droge stof ${ }^{15}$. Onder aanname dat de vraag ongeveer gelijk op gaat met de totale energievraag, zal hiervoor in 2050 ongeveer 1,4Gton droge stof gevraagd worden.

De totalen zijn samengevat in onderstaande tabel.

\footnotetext{
14 IEA Technology Roadmap: Bioenergy for Heat and Power (2012)

15 PBL (2014): G.J. van den Born, J.G. van Minnen, J.G.J. Olivier \& J.P.M. Ros: Integrated analysis of global biomass flows in search of the sustainable potential for bioenergy production, PBL report 1509, PBL, The Netherlands.
} 
Tabel 8. Overzicht van huidige en verwachte mondiale vraag naar biomassa voor biobased toepassingen.

\begin{tabular}{lcc}
\hline Categorie & Huidige mondiale vraag & Verwachte mondiale vraag 2050 \\
\hline Energie/brandstoffen & $3 \mathrm{Gton} / \mathrm{jr}$ & 9 à $10 \mathrm{Gton} / \mathrm{jr}$ \\
\hline Chemicaliën/plastics & $0 \mathrm{Gton} / \mathrm{jr}$ & $0,5 \mathrm{Gton} / \mathrm{jr}$ \\
\hline Vezels/materialen & $1 \mathrm{Gton} / \mathrm{jr}$ & $1,4 \mathrm{Gton} / \mathrm{jr}$ \\
\hline Totaal & $4 \mathrm{Gton} / \mathrm{jr}$ & 11 à $12 \mathrm{Gton} / \mathrm{jr}$ \\
\hline
\end{tabular}

\subsection{Verwachte Nederlandse vraag nar biomassa voor biobased toepassingen}

Huidige en verwachte Nederlandse vraag is samengevat in onderstaande tabel. Onderliggende analyse is gegeven in Appendix $\mathrm{E}$.

Tabel 9. Huidige en verwachte Nederlandse vraag naar biomassa voor biobased (Mton droge stof per jaar)

\begin{tabular}{|c|c|c|c|c|}
\hline Toepassing & $\begin{array}{c}\text { Huidige } \\
\text { vraag }\end{array}$ & $\begin{array}{c}\text { Verwachte vraag } \\
2030^{16} \\
\end{array}$ & $\begin{array}{c}\text { Verwachte vraag } \\
2050^{17}\end{array}$ & $\begin{array}{c}\text { Verwachte vraag } \\
2050^{18} \\
\end{array}$ \\
\hline Biobased & 6,5 & $25-35$ & 94 & \\
\hline \multicolumn{5}{|l|}{ waarvan } \\
\hline materiaal/chemie & 3 & $10-14$ & $8-10$ & \\
\hline
\end{tabular}

Opmerkingen bij deze tabel:

- $\quad$ Een onderbouwing voor de cijfers voor de huidige vraag naar biomassa voor biobased is gegeven in Appendix B. Ten opzichte van cijfers van CE Delft (2017) en Kwant et al. zijn recyclestromen en exportstromen weggelaten.

- Verschillen tussen twee scenario's voor 2050 zijn illustraties voor de huidige onzekerheid en verschil in visies. Verschillende verwachtingen over omgevingsfactoren, zoals succes van alternatieve duurzame energievormen zullen grote invloed hebben.

- Verwachte vraag naar biomassa voor materialen in 2050 ligt volgens deze tabel lager dan in 2030; dit lijkt niet consistent. PBL benoemt alleen ambities van industrie t.a.v. plastics; waarschijnlijk zijn daarbij veel andere behoeftes niet meegenomen. We hebben de vraag in 2050 t.o.v. de cijfers van PBL al opgehoogd met het huidige verbruik. Waarschijnlijk ontbreken ook nog andere behoeftes in de schatting in bovenstaande tabel, en valt de vraag voor materialen in 2050 hoger uit.

- De weergegeven biomassavraag voor energieopwekking in 2050 is opgesplitst naar 27-41PJ voor warmte en 23-29PJ voor elektriciteit.

\footnotetext{
16 Op basis van Visiedocument Biomassa 2030

17 Op basis van PBL 2013: Biomassa: wensen en grenzen.

18 Scenario waarin NL het door IEA (2012) voorspelde mondiale aandeel energie uit biomassa volgt (dat is ongeveer $14 \%$ voor warmte en elektriciteit en $8 \%$ voor brandstoffen)

${ }^{19}$ Met grootschalige bij- en meestook en groen gas.
} 


\section{$4 \quad$ Samenvattend overzicht en concluderende opmerkingen}

In dit rapport is een kwantitatieve analyse gepresenteerd naar verwachte vraag en beschikbaarheid in 2030 en 2050. De resultaten zijn samengevat in onderstaande tabellen.

\section{Wereld}

Tabel 10. Geschatte mondiale productie/theoretische beschikbaarheid (Gton droge stof per jaar)

\begin{tabular}{lccc}
\hline Categorie & Huidige productie & $\mathbf{2 0 3 0}$ & $\mathbf{2 0 5 0}$ \\
\hline Voedselproducten & 1,5 & 1,8 & 2,1 \\
\hline Veevoeders & 6,6 & 7,8 & 9,2 \\
\hline Overige biomassa & 4 & $\leq 13$ \\
\hline
\end{tabular}

Tabel 11. Huidige en verwachte vraag (Gton droge stof per jaar)

\begin{tabular}{lcc}
\hline Categorie & Huidige vraag & $\mathbf{2 0 5 0}$ \\
\hline Voedselproducten & 1,5 & 2,4 \\
\hline Veevoeders & 6,6 & 8,3 \\
\hline Overige biomassa & 4 & 11 à 12 \\
\hline Waarvan: energie/brandstoffen & 3 & 9 à 10 \\
\hline Chemicaliën/plastics & 0 & 0,5 \\
\hline Vezels/materialen & 1 & 1,4 \\
\hline
\end{tabular}

Let op: indicaties voor biobased productiepotentieel is de som van alle jaarlijkse aanwas van biomassa die niet wordt gebruikt voor voedsel of veevoeders. Aanzienlijk deel daarvan is niet beschikbaar (o.a. t.b.v. op peil houden van bodemkwaliteit) of kan alleen tegen hoge kosten (inclusief energiekosten) beschikbaar gemaakt worden. Andere oplossingen binnen het agri-food-biobased systeem (zoals biomassateelt, eiwittransitie) zullen noodzakelijk zijn. Ook oplossingen buiten het agri-food systeem kunnen en zullen noodzakelijk zijn (denk aan andere alternatieve energiebronnen).

\section{Nederland}

Tabel 12. Verwachte beschikbaarheid uit de Nederlandse land- en bosbouw en bijproducten.

\begin{tabular}{lccc}
\hline Categorie & Huidige productie & $\mathbf{2 0 3 0}$ & $\mathbf{2 0 5 0}$ \\
\hline Voedsel & $4-5$ & $4,4-5,5$ & $4,7-5,8$ \\
\hline Veevoeders & 23 & 25 & 27 \\
\hline Biobased & 0,2 & 0,2 & 0,2 \\
\hline
\end{tabular}

Tabel 13. Samenvatting van huidige en verwachte vraag naar biomassa (droge stof Mton/jaar) voor voedsel, veevoeders en biobased toepassingen in Nederland in 2030.

\begin{tabular}{lccr}
\hline Toepassing & Huidige vraag & Verwachte vraag 2030 & Verwachte vraag 2050 \\
\hline Voedsel & 4,45 & $4,5-4,9$ & $4,4-5,2$ \\
\hline Veevoeders & 28 & $27-31$ & $25-29$ \\
\hline Biobased & 6,5 & $25-35$ & 94 \\
\hline waarvan materiaal & 3 & $10-14$ & $8-10$ \\
\hline Warmte + elektr. & 3 & 12 & $25-70$ \\
\hline transport brandst. & 0,5 & $3.5-10$ & $14-29$ \\
\hline
\end{tabular}

Volgens bovenstaande tabellen is en blijft op drogestof-basis de Nederlandse voedselvraag redelijk in evenwicht met de productie; allicht met grote import-export verschillen tussen de verschillende voedselcategorieën.

De veehouderij is en blijft netto vleesexporteur, maar tegelijkertijd blijft de sector afhankelijk van een aanzienlijke import van veevoedergrondstoffen. 
Voor non-food biomassa wordt geconcludeerd dat alleen indien alle theoretisch beschikbare Nederlandse biomassastromen zonder verlies worden aangewend, de Nederlandse biobased behoefte voor 2030 kunnen worden ingevuld. Richting 2050 wordt de afhankelijkheid van import nog veel sterker. 


\section{Appendix A. Projection of food consumption for 2030 and 2050 according to FAO}

We derived food need from FAO $(2012)^{20}$. That work presents a thorough analysis of "current" (2005/2007) and expected food consumption (2050), differentiating between continents and major food commodities.

The basic unit expressing food consumption is metabolizable energy (kcal). We have derived/estimated total food consumption (dry) matter and main food components through the following analyses:

- Protein, fat and carbohydrates estimate: In literature, food consumption data are expressed in caloric value. This can be detailed to protein and fat consumption through data from FAOSTAT $^{21}$. We estimate the carbohydrates consumption through subtracting average caloric value of the consumed protein and fats.

- We estimate $25 \mathrm{~g}$ dietary fibres in the food (not contributing to metabolizable energy), in line with the data from Giovannucci et al., 1994 and we assumed 5\% other dry matter (minerals, etc.). The total amount of non-protein/fat/carbohydrates resulting from this analysis is quite well in line with the assumptions made by Piotrowski et al., 2015a. They assumed 10\% nonmetabolizable substances.

Tabel 14. NL Food supply (2006 and 2013 data from FAOSTAT, projections for 2030 and 2050 based on growth ratios for developed countries by FAO, 2012)

\begin{tabular}{lcccc}
\hline Food supply (kcal per capita per day) & $\mathbf{2 0 0 6}$ & $\mathbf{2 0 1 3}$ & $\mathbf{2 0 3 0}$ & $\mathbf{2 0 5 0}$ \\
\hline Protein supply (gram per capita per day) & 3213 & 3228 & 3266 & 3323 \\
\hline Fat supply (gram per capita per day) & 109 & 112 & 113 & 115 \\
\hline $\begin{array}{l}\text { Carbohydrates (gram per capita per day) } \\
\text { (calculated from kcal, minus protein and fat component) }\end{array}$ & 132 & 126 & 127 & 130 \\
\hline Fibres and other dry matter (estimated: 10\%) & 397 & 413 & 418 & 425 \\
\hline TOTAL dry matter food supply (gram per capita per day) & & & & \\
\hline
\end{tabular}

Tabel 15. Changes in the commodity composition of food for developed countries (kg per capita per year)

\begin{tabular}{|c|c|c|c|c|c|c|}
\hline Category & $\begin{array}{c}1969 / \\
1971 \\
\end{array}$ & $\begin{array}{c}1979 / \\
1981 \\
\end{array}$ & $\begin{array}{c}1989 / \\
1991 \\
\end{array}$ & $\begin{array}{c}2005 / \\
2007\end{array}$ & 2030 & 2050 \\
\hline Cereals, all uses & 571 & 620 & 618 & 591 & 682 & 695 \\
\hline Sugar and sugar crops (raw sugar eq.) & 41 & 40 & 36 & 34 & 33 & 33 \\
\hline Pulses, dry & 3.6 & 2.9 & 2.9 & 2.9 & 3.0 & 3.1 \\
\hline Vegetable oils, oilseeds and products (oil eq.) & 11 & 14 & 16 & 19 & 20 & 21 \\
\hline Other food (kcal/person/day) & 492 & 508 & 498 & 458 & 488 & 509 \\
\hline Total food (kcal/person/day) & 3138 & 3222 & 3288 & 3360 & $\begin{array}{c}3 \\
430\end{array}$ & $\begin{array}{c}3 \\
490\end{array}$ \\
\hline
\end{tabular}

Annual growth rate of meat production in developed countries: $0.4 \%$.

Annual growth rate of livestock production in developed countries: 2007-2030: 0.6\%; 2030-2050: $0.2 \%$.

\footnotetext{
${ }^{20}$ FAO (2012): World Agriculture towards 2030/2050. The 2012 Revision, ESA Working Papers No. 12-03, Agricultural Development Economics Division, Food and Agriculture Organization of the United Nations.

${ }^{21} \mathrm{http}: / /$ faostat3.fao.org/browse/FB/FBS/E
} 


\section{Appendix B. Diepgaandere analyse voedselconsumptie}

In statistieken worden verschillende cijfers t.a.v. voedselvraag gehanteerd. FAOSTAT schat voedselbeschikbaarheid; dit omvat ook verliezen en inefficiënties bij de consument. In cijfers van voedselconsumptiepatronen (zoals van RIVM) is alleen de daadwerkelijke voedselinname verwerkt, dus exclusief verliezen voor consumptie. Statistieken naar totale voedselbeschikbaarheid geven dus hogere cijfers dan statistieken naar consumptiepatronen ${ }^{22}$. Verliezen en inefficiënties worden logischerwijze meegenomen in de totale marktvraag naar voedsel; daarom worden berekeningen op basis van voedselbeschikbaarheidscijfers zoals door FAOSTAT het meest relevant geacht.

Een aanzienlijk deel van het voedsel wordt be- of verwerkt voordat het de consument bereikt. Een flink deel de be-/verwerkte voedselproducten wordt geïmporteerd resp. geëxporteerd. De totale Nederlandse vraag naar voedselgewassen omvat in feite ook de benodigde inputs voor deze exportproducten. Echter, omdat geen detailcijfers over het volume van de voedselindustrie bekend $\mathrm{zijn}^{23}$, is dit facet niet meegenomen in onderstaande analyses.

Een doorkijk naar 2030 en 2050 wordt in dit rapport geschetst vanuit zowel verwachte verschuivingen in consumptiepatroon (waarbij verwacht mag worden dat die ook in de voedselvraag naar voren zal komen) als in verwachte ontwikkelingen van voedselproductie.

RIVM onderzoekt in diverse studies verschuivingen in consumptiepatronen, opgesplitst naar verschillende product-categorieën. Door extrapolatie kunnen verwachtingen t.a.v. voedselconsumptie op de langere termijn worden geschetst, in het bijzonder verschuivingen tussen voedselcategorieën. RIVM maakt ook vergelijkingen met richtlijnen goede voeding. Ook die vergelijking vormt een basis voor de doorkijk in dit rapport.

FAO heeft schattingen gemaakt t.a.v. totale voedselvraag. Nederland valt daarbij in de categorie 'Ontwikkelde landen'. Extrapolaties van FAO zijn wat minder gedetailleerd dan van RIVM; FAO beperkt zich tot componenten zoals koolhydraten, eiwitten en oliën/vetten.

De (ten opzichte van ontwikkelende landen) beperkte veranderingen voor ontwikkelde landen volgens FAOSTAT zien we ook in voorspellingen volgens RIVM.

\section{Huidige consumptie}

Het actuele consumptiepatroon is beschreven in een aantal recente publicaties, waaronder RIVM $(2016)^{24}$ : Tabel 16.

Tabel 16. Gemiddelde voedselconsumptie van de Nederlandse bevolking (VCP 2012-2014)

\begin{tabular}{lc} 
Categorie & $\begin{array}{l}\text { Gemiddelde consumptie } \\
\text { (gram per dag per capita) }\end{array}$ \\
\hline Aardappelen en andere knolgewassen & 73 \\
\hline Groenten & 127 \\
\hline Peulvruchten & 4 \\
\hline Fruit en compote & 112 \\
\hline Noten en zaden & 9 \\
\hline Olijven & 1 \\
\hline Zuivelproducten en -vervangers & 355 \\
\hline
\end{tabular}

${ }^{22}$ Ter vergelijking: volgens schattingen van USDA is in de USA gemiddeld $3900 \mathrm{kcal} / \mathrm{dag} /$ persoon beschikbaar; na aftrek van "verspilling en andere verliezen" resteert dan $2700 \mathrm{kcal}$ (http://www.ers.usda.gov/Data/ FoodConsumption/NutrientAvailIndex.htm)

${ }^{23}$ CBS geeft wel diverse financiële indicatoren, maar geen volume-cijfers.

${ }^{24}$ Van Rossum, C.T.M., E.J.M. Buurma-Rethans, F.B.C. Vennemann, M.H. Beukers, H.A.M. Brants, E.J. de Boer \& M.C. Ocké: The diet of the Dutch. Results of the first two years of the Dutch National Food Consumption Survey 2012-2016, RIVM Letter report 2016-0082, 2016. 


\begin{tabular}{ll}
\hline Categorie & $\begin{array}{l}\text { Gemiddelde consumptie } \\
\text { (gram per dag per capita) }\end{array}$ \\
\hline Granen en graanproducten incl. rijst & 192 \\
\hline Vlees en vleesproducten & 99 \\
\hline Vleesvervangers & 2 \\
\hline Vis, schelpdieren en amfibieën & 15 \\
\hline Eieren en eiproducten & 12 \\
\hline Vetten en oliën & 22 \\
\hline Suiker en suikergoed & 38 \\
\hline Koek en gebak & 39 \\
\hline Niet-alcoholische dranken excl. water & 1086 \\
\hline Alcoholische dranken & 152 \\
\hline Kruiden, specerijen, sausen en gist & 37 \\
\hline Soep en bouillons & 24 \\
\hline Hartige snacks & 20 \\
\hline
\end{tabular}

RIVM (2017) ${ }^{25}$ vergelijkt de actuele consumptiecijfers met de richtlijnen goede voeding. Belangrijke conclusie luidt dat voor verschillende productcategorieën de actuele consumptie sterk van de richtlijnen afwijken:

"De consumptie van een aantal productgroepen zit in de buurt van de aanbevolen hoeveelheden in de richtlijnen. Zo eet meer dan de helft van de volwassenen de aanbevolen enkele porties zuivel per dag. Daarnaast is ongeveer twee derde van de gebruikte smeer- en bereidingsvetten smeerbaar of vloeibaar; de richtlijn beveelt aan vetten zo veel mogelijk in deze vorm te gebruiken. Ook eet bijna de helft van de volwassen Nederlanders conform de desbetreffende richtlijn minstens 90 gram bruin en volkoren graanproducten per dag.

Een paar andere productgroepen staan er verder van af. Minder goed gaat het bijvoorbeeld met de consumptie van groente: slechts 15 procent van de volwassenen eet de aanbevolen hoeveelheid van dagelijks 200 gram groente. Eenzelfde percentage haalt de richtlijn voor fruit (200 gram fruit). Verder eet circa een op de vijftien volwassenen de aanbevolen hoeveelheid noten van 15 gram of meer per dag. Peulvruchten staan eens in de drie weken op het menu, in plaats van wekelijks. Ook drinkt vrijwel iedereen suikerhoudende dranken (inclusief vruchtensappen): gemiddeld twee kleine glazen per dag terwijl de Gezondheidsraad aanbeveelt daar zo min mogelijk van te nemen."

Belangrijkste hieruit af te leiden aanbevelingen doelen op het verhogen van consumptie van groente en fruit en het verhogen van het aandeel plantaardige eiwitten. Dit is in lijn met het uitgezette beleid volgens de voedselagenda.

Trends in voedselconsumptie vertonen beperkte verschuivingen tussen de onderscheiden productcategorieën (Figuur 2). Grootste veranderingen zijn afname van consumptie van aardappelen en vetten en oliën en toename van consumptie van sauzen. Dit kan verklaard worden met de trend naar meer gemaks- en bewerkte voedselproducten.

${ }^{25}$ Van Rossum, C.T.M., E.J.M. Buurma, F.B.C. Vennemann, M.H. Beukers, J.J.M.M. Drijvers \& M.C. Ocké: Voedselconsumptie in 2012-2014 vergeleken met de Richtlijnen goede voeding 2015, RIVM Briefrapport 2017-0095, 2017. 


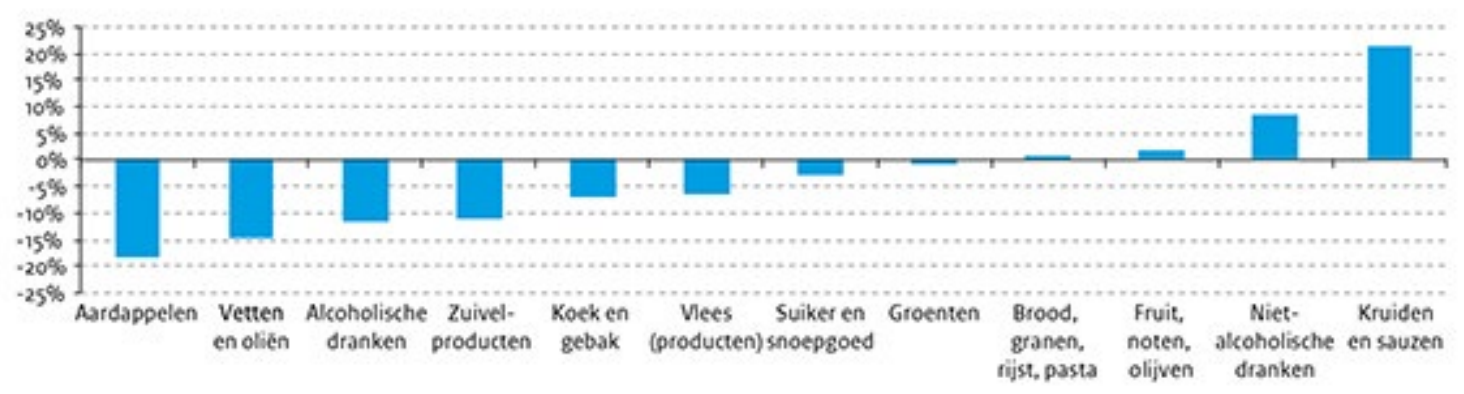

Figuur 2. Verandering in voedselconsumptie per capita, 9-69-jarigen (voedselconsumptiepatroon 2012-2014 vergeleken met voedselconsumptiepatroon 20072010) $)^{26}$.

De afname in vleesconsumptie (Figuur 2) wordt bevestigd door Terluin et al. ${ }^{27}$ : in de jaren 2005-2010 schommelde de vleesconsumptie rond $80 \mathrm{~kg}$ per jaar per hoofd van de bevolking, vanaf 2010 is een lichte daling in gang gezet tot $75 \mathrm{~kg}$ in 2015 (het laatst gerapporteerde jaar).

In calorieën uitgedrukt bedraagt de gemiddelde Nederlandse voedselconsumptie 2247kCal per dag (cijfers over 2007-2010, zie Tabel 17). Dat komt neer op ongeveer 500 gram droge stof per persoon per dag ${ }^{28}$, ofwel $182 \mathrm{~kg}$ per capita per jaar. Totale consumptie van 17 miljoen inwoners bedraagt dan 3,1 Mton droge stof per jaar.

Tabel 17. Gemiddelde voedselconsumptie per Nederlander uitgedrukt in grammen en kcal per persoon per dag (voedselconsumptiepatroon VCP2007-2010 volgens RIVM ${ }^{29}$ )

Voedingsmiddelengroepen

Gemiddelde consumptie (gram/dag)

\begin{tabular}{lcc}
\hline Groente & 121 & 36 \\
\hline Fruit & 108 & 68 \\
\hline Vruchtensappen & 69 & 30 \\
\hline Peulvruchten & 3 & 3 \\
\hline Aardappelen, pasta, rijst & 142 & 184 \\
\hline Brood en broodvervangers & 146 & 386 \\
\hline Melk(producten) & 329 & 189 \\
\hline Kaas & 34 & 118 \\
\hline Onbewerkt vlees & 68 & 144 \\
\hline Bewerkt(e) vlees(producten), & 52 & 134 \\
Vleeswaren, vleesvervangers & & \\
\hline Vis & 15 & 24 \\
\hline Oliën en vetten & 27 & 156 \\
\hline Water, koffie en thee & 1248 & 56 \\
\hline Soepen & 54 & 20 \\
\hline Sauzen & 29 & 73 \\
\hline Hartige snacks & 25 & 108 \\
\hline Zoete snacks & 65 & 232 \\
\hline Alcoholische dranken & 185 & 111 \\
\hline Niet-alcoholische dranken & 384 & 100 \\
\hline Broodbeleg & 18 & 2247 \\
\hline & & \\
\hline & & \\
\hline
\end{tabular}

${ }^{26}$ RIVM, VCP, Voedselconsumptiepatronen, 2012-2016, 1-79 jaar, http://www.rivm.nl/Onderwerpen/V/Voedselconsumptiepeiling/Overzicht_voedselconsumptiepeilingen/VCP_Basis_1_79_ja ar_2012_2016\#Resultaten

27 Terluin, I., H. Dagevos, D. Verhoog \& H. Wijsman: Vleesconsumptie per hoofd van de bevolking in Nederland, 2005-2015, Wageningen Economic Research, Nota 2016-097, 2016.

28 Berekend met conversie-parameters zoals in Appendix A.

${ }^{29}$ M. Geurts \& C.T.M. van Rossum: De Nederlandse voedselconsumptie vergeleken met de Richtlijnen voedselkeuze. Resultaten op basis van de Nederlandse Voedselconsumptiepeiling 2007-2010. RIVM Briefrapport 2014-0135 (2014). 


\section{Appendix C. Scenario's voor ontwikkeling Nederlandse voedselvraag}

De ontwikkeling van de Nederlandse voedselvraag hangt af van demografische ontwikkeling en consumptie per hoofd van de bevolking.

\section{Demografische ontwikkeling Nederland}

Voor het inschatten van de totale voedselvraag in Nederland is - naast consumptie per inwoner demografische ontwikkeling een belangrijke factor. Voor demografische ontwikkeling wordt hier verwezen naar de WLO referentiescenario's van CPB/PBL ${ }^{30}$ : Hoog en Laag. "Scenario Hoog combineert een hoge economische groei van 2 procent per jaar met een relatief sterke bevolkingsaanwas. En in scenario Laag gaat een gematigde economische groei van 1 procent per jaar samen met een beperkte demografische ontwikkeling." Demografische ontwikkelingen hangen volgens deze scenario's vooral af van migratie; verwachte bevolkingsaantallen zijn weergegeven in Tabel 18.

Tabel 18. Ontwikkeling Nederlandse bevolking (miljoenen inwoners) in 2030 en 2050 volgens WLO scenario's

\begin{tabular}{lcc}
\hline Jaar & $\mathbf{2 0 3 0}$ & $\mathbf{2 0 5 0}$ \\
\hline Scenario Laag & 17,1 & 16,4 \\
\hline Scenario Hoog & 18,1 & 19,3 \\
\hline
\end{tabular}

\section{Scenario's voor voedselvraag in 2030 en 2050}

1. Demografische ontwikkeling volgens WLO scenario Laag, in combinatie met ontwikkeling van de gemiddelde voedselvraag volgens FAO.

2. Demografische ontwikkeling volgens WLO scenario Hoog, in combinatie met ontwikkeling van de gemiddelde voedselvraag volgens FAO.

3. Verschuiving van eiwitconsumptie naar plantaardig, demografische ontwikkeling volgens WLO scenario Laag.

4. Idem, WLO scenario Hoog.

In visiedocumenten over eiwittransitie worden kwantitatieve doorkijken naar 2030/2050 genoemd. Daarom poneren we hier voor scenario's 3 en 4 zelf een traject: $10 \%$ en $33 \%$ van het dierlijk eiwit is vervangen door plantaardige alternatieven in 2030 resp. 2050.

Vervanging van dierlijk door plantaardig eiwit kan een effect hebben op de hoeveelheid geconsumeerd eiwit. De meeste plantaardige eiwitten hebben een wat lagere biologische waarde (uitgedrukt met de indicator PDCAAS) dan dierlijk eiwit. Bij een vergelijking van diëten met dezelfde biologische waarde hoort daarom in een overwegend plantaardig dieet een wat hogere eiwitconsumptie dan bij een dieet dat rijk is aan dierlijke eiwitten: rond 20\% extra eiwitten. Daarom wordt in scenario's 3 en 4 gerekend met een hogere inname van eiwitten: $45^{31}$ gram dierlijke eiwitten worden vervangen door 54 gram plantaardige.

Indirecte effecten - minder ruimte- en voerbehoefte voor veehouderij - wordt hier niet meegenomen.

\footnotetext{
${ }^{30}$ T. Manders \& C. Kool: (2015):Toekomstverkenning Welvaart en Leefomgeving. Nederland in 2030 en 2050: twee referentiescenario's, CPB/PBL.

${ }^{31}$ Natuur \& Milieu: Voedselvisie. Naar een gezond en duurzaam voedselsysteem in 2013, 2017.
} 
Tabel 19. Ontwikkeling voedselvraag van Nederlandse consumenten (Mton/jaar) bij de scenario's

\begin{tabular}{llll}
\hline Jaar & Nu & $\mathbf{2 0 3 0}$ & $\mathbf{2 0 5 0}$ \\
\hline Scenario 1 & 4,45 & 4,52 & 4,41 \\
\hline Scenario 2 & 4,45 & 4,79 & 5,20 \\
\hline Scenario 3 & 4,45 & 4,55 & 4,45 \\
\hline Scenario 4 & 4,45 & 4,82 & 5,24 \\
\hline
\end{tabular}

Samengevat wordt de voedselvraag in 2030 geschat op 4,5 tot 4,9 Mton en in 2050 op 4,4 tot 5,2 Mton droge stof. 


\section{Appendix D. Analyse veevoedervraag}

\section{Huidige vraag naar veevoeders}

Mengvoeders, waarvoor de grondstoffen voor het overgrote deel afkomstig zijn van import:

- Totale EU-28 markt (2017 ${ }^{32}$ ) 153 Mton. Bij een geschat drogestofgehalte van $90 \%$ betekent dit totaal 138 Mton droge stof.

- De Nederlandse afzet van mengvoeders schommelt rond 12,5Mton (bron: cijfers van NEVEDI); dat is ongeveer 11 Mton droge stof $\left(2015^{33}\right)$.

Ruwvoeders:

- Totale EU-28 productie (FEFAC, 2017): 233 Mton; bij een geschat drogestofgehalte van 85\%: 198 Mton.

- $\quad$ NL schatting: bij een grasland-areaal van 960.000 hectare (bron: CBS), met drogestofopbrengst rond 11,1 ton ds per hectare, wordt de totale opbrengst geschat op 11 Mton ds gras per jaar. Verliezen worden hier verwaarloosd (dus we nemen aan dat het verbruik gelijk is aan de opbrengst).

Veevoedergewassen:

- Dominante gewassen in $\mathrm{NL}_{\text {zijn }}^{34}$ : snijmaïs (totale jaarlijkse opbrengst varieert rond 9 Mton, dat is ongeveer 3 Mton droge stof van 200.000 hectare) en andere granen (totale jaarlijkse opbrengst rond 1,5 Mton, dat is ongeveer 1,3 Mton droge stof van 150.000 hectare).

Vochtrijke veevoeders:

- $\quad$ NL productie 35 5,6 Mton, met ds. gehalte 19,8\%, dus totaal 1,1 Mton droge stof.

Ruwvoeders, veevoedergewassen en vochtrijke veevoeders worden voor het grootste deel gebruikt in het land van herkomst.

Tabel 20. Samenvatting huidige veevoedervraag in Nederland (Mton droge stof per jaar).

\begin{tabular}{lc}
\hline Categorie & Huidige vraag \\
\hline Mengvoeders & 11 \\
\hline Gras & 11 \\
\hline Overige veevoedergewassen & 5 \\
\hline Vochtrijke veevoeders & 1 \\
\hline TOTAAL & 28 \\
\hline
\end{tabular}

Toekomstige ontwikkeling van de veevoedervraag op basis van WLO scenario's is uitgewerkt in onderstaande tabel.

Tabel 21. Verwachte ontwikkeling van veestapel en veevoedervraag in 2030 en 2050, gebaseerd op verschillende toekomstscenario's ${ }^{36}$.

\begin{tabular}{|c|c|c|c|}
\hline & 2017 & 2030 & 2050 \\
\hline Verwachte voervraag per dier $(2017=100)$ & 100 & 102 & 104 \\
\hline Totale veevoedervraag in NL (Mton/jaar) & 28 & $27-31$ & $25-29$ \\
\hline
\end{tabular}

\footnotetext{
32 FEFAC: Annual report 2016-2017, 2017.

33 FEFAC: Feed \& Food. Statistical yearbook 2015, 2016.

34 Cijfers: CBS. http://statline.cbs.nl/StatWeb/publication/?PA=7100oogs (geraadpleegd 19 september 2017).

35 Overleggroep Producenten Vochtrijke Veevoeders: Afzet vochtrijke diervoeders weer toegenomen (2017).

${ }^{36}$ G.J. van den Born \& M. van Schijndel: Landbouw achtergronddocument. WLO - Welvaart en Leefomgeving. Toekomstverkenning 2030 en 2050, CPB/PBL, 2016.
} 
Zoals blijkt uit bovenstaande tabel gaan de WLO scenario's uit van min of meer gelijkblijvende productie van dierlijke eiwitten. Als, anderzijds, de eiwittransitie steviger doorzet en de Nederlandse veehouderij zich daarop aanpast, zal de hoeveelheid benodigd veevoer navenant afnemen. Met het oog op de lage eiwitefficiëntie van dierlijke productie (bijvoorbeeld 8,3\% voor varkens, 23\% voor kip en $22 \%$ voor melk ${ }^{37}$ ), is netto een aanzienlijke efficiëntieverbetering mogelijk (mits het extractieproces van plantaardig eiwitgewas naar voedselproduct aanzienlijk efficiënter is dan de genoemde percentage voor dierlijke productie). Een nadere analyse naar voederrantsoen en herkomst en opbrengst van de ingrediënten alsmede mogelijke opbrengsten van eiwitrijke voedingsgewassen en biologische waarde van het eiwit is nodig om efficiëntieverbeteringen goed in te schatten, maar valt buiten het kader van het hier gerapporteerde onderzoek.

\footnotetext{
37 L.B.J. Šebek \& E.H.M. Temme: De humane eiwitbehoefte en eiwitconsumptie en de omzetting van plantaardig eiwit naar dierlijk eiwit, Wageningen UR Animal Sciences Group, Rapport 232, 2009.
} 


\section{Appendix E. Huidige vraag naar biomassa voor non-food in Nederland}

Het huidige verbruik van biomassa voor non-food toepassingen is door CE Delft ${ }^{38}$ gedetailleerd in kaart gebracht. RVO heeft op basis daarvan een samenvattend overzicht gemaakt (Tabel 22).

Tabel 22. Biomassa benutting voor non-food/feed toepassingen in Nederland in $2015^{39}$.

\begin{tabular}{ll}
\hline Toepassing & Biomassa (Mton per jaar) \\
\hline Materiaal hout/papier & 6,8 \\
\hline Materiaal olien/vetten/zetmeel & 0,2 \\
\hline Totaal gebruik voor Materiaal & $\mathbf{7 , 0}$ \\
\hline consumptie biotransportbrandstof & 0,4 \\
\hline export biotransport brandstof & 1,5 \\
\hline hout voor electriciteit/warmte & 2,4 \\
\hline andere biomassa voor energie & 2,0 \\
\hline Totaal gebruik voor Energie & $\mathbf{6 , 3}$ \\
\hline TOTAAL & $\mathbf{1 3 , 3}$ \\
\hline
\end{tabular}

Volgens dit overzicht schommelt de vraag rond 13 Mton per jaar.

Daarbij zijn echter, afgaand op details in het rapport van CE Delft, een aantal kanttekeningen op z'n plaats:

- Pulp en papier:

- Uitgaande van 2,4Mton (droge stof) pulp wordt 2,6Mton papier geproduceerd. Daarvan wordt 0,5Mton in Nederland verbruikt en 2,1Mton geëxporteerd.

- Daarnaast wordt in Nederland 2,0Mton papier verbruikt (1,9 ton droog), afkomstig uit import.

CE Delft telt de import bij de Nederlandse papierproductie, met als resultaat een totaal verbruikscijfer van 4,3Mton droge stof. Hoewel de papier-import wel wordt meegerekend, wordt blijkbaar het verbruik samenhangend met export niet gecompenseerd in de cijfers. Wij zijn echter van mening dat òf zowel import als export niet worden meegenomen, òf beide cijfers dat beide factoren worden meegenomen in de vraag-analyse. Dit leidt in beide gevallen tot een totale behoefte van 2,4Mton. Dus, de netto vraag naar biomassa voor "Materiaal hout/papier" ligt 1,9Mton (afgerond 2Mton) lager dan volgens bovenstaande tabel.

- Dubbeltellingen in relatie tot hergebruik:

- De biomassavraag voor pulp/papier wordt voor 2 Mton ingevuld door gerecycled papier.

- Een aanzienlijk deel van gebruikt hout wordt hergebruikt: in de houtindustrie (200kton), voor energieproductie (800kton) en wordt als product (400kton) geëxporteerd. Totaal binnenlands hergebruik ligt rond 1Mton.

Totaal wordt van de behoefte dus ongeveer 3Mton ingevuld door hergebruik.

- $\quad$ Export biotransport brandstof (1,5Mton): aangezien dit wordt geëxporteerd telt het feitelijk niet mee bij de Nederlandse vraag.

Conclusie: De huidige netto vraag naar biomassa voor biobased toepassingen is ongeveer $13-2-3-1,5$ $=6,5$ Mton.

\footnotetext{
${ }^{38}$ Van Lieshout, M. \& T. Scholten (2017): Sustainable biomass and bioenergy in the Netherlands. Report 2016, CE Delft publicatie 17.3J93.41, Delft.

39 Kwant, K., W. Siemers, A. Hamer \& D. Both (2017): Monitoring biobased economy in Nederland 2016, RVO Rijksdienst voor Ondernemend Nederland.
} 
Toekomstige vraagontwikkeling wordt geschetst in verschillende bronnen (zie paragraaf 3.4). Ten aanzien van de voorspelling van IEA (2012):

Huidig totaal primair energieverbruik in NL schommelt tussen 2006 en 2016 tussen 3000 en 3500 J J $^{40}$. Daarvan is ongeveer $1 / 6$ toe te rekenen aan transportbrandstoffen ${ }^{41}$. ECN ${ }^{42}$ voorziet voor 2030 een nationaal primair energieverbruik van 3100PJ. Extrapolerend naar 2050 zou dat rond 3000PJ liggen. Huidige productie energie uit biomassa (exclusief afvalstromen) bedraagt 50PJ, dat is dus ruim 1,5\%. Als NL het door IEA (2012) voorspelde mondiale aandeel energie uit biomassa zou halen (dat is ongeveer $14 \%$ voor warmte en elektriciteit en $8 \%$ voor brandstoffen): 420 PJ warmte en elektriciteit ( 25Mton/jr), transportbrandstoffen 14 Mton/jr.

40 CBS Energiebalans

41 CBS (2012): Het energieverbruik voor warmte afgeleid uit de Energiebalans. Update 2010

42 ECN (2015): Nationale Energieverkenning 2015. 


\section{Appendix F. Potentieel van non-food biomassa productie in Nederland}

De Commissie Duurzaamheidsvraagstukken Biomassa ${ }^{43}$ geeft een overzicht cijfers uit verschillende literatuur-bronnen (Tabel 23). In het rapport wordt op basis van de verschillende cijfers een bandbreedte voor beschikbare Nederlandse biomassa vastgesteld tussen 150 en $400 \mathrm{PJ}$, dat is in droge stof (uitgaande van 17MJ per ton) 9 tot 24Mton. De grote bandbreedte hangt samen met onzekerheden over:

- mogelijkheden om de biomassa daadwerkelijk beschikbaar te kunnen maken;

- wet- en regelgeving (bijvoorbeeld voor biomassa uit natuurgebieden);

- $\quad$ ontwikkeling van aquacultuur en energieteelt;

- etc.

Tabel 23. Primaire energie-inhoud van beschikbare biomassa in Nederland voor non-food en non-feed toepassingen volgens verschillende studies.

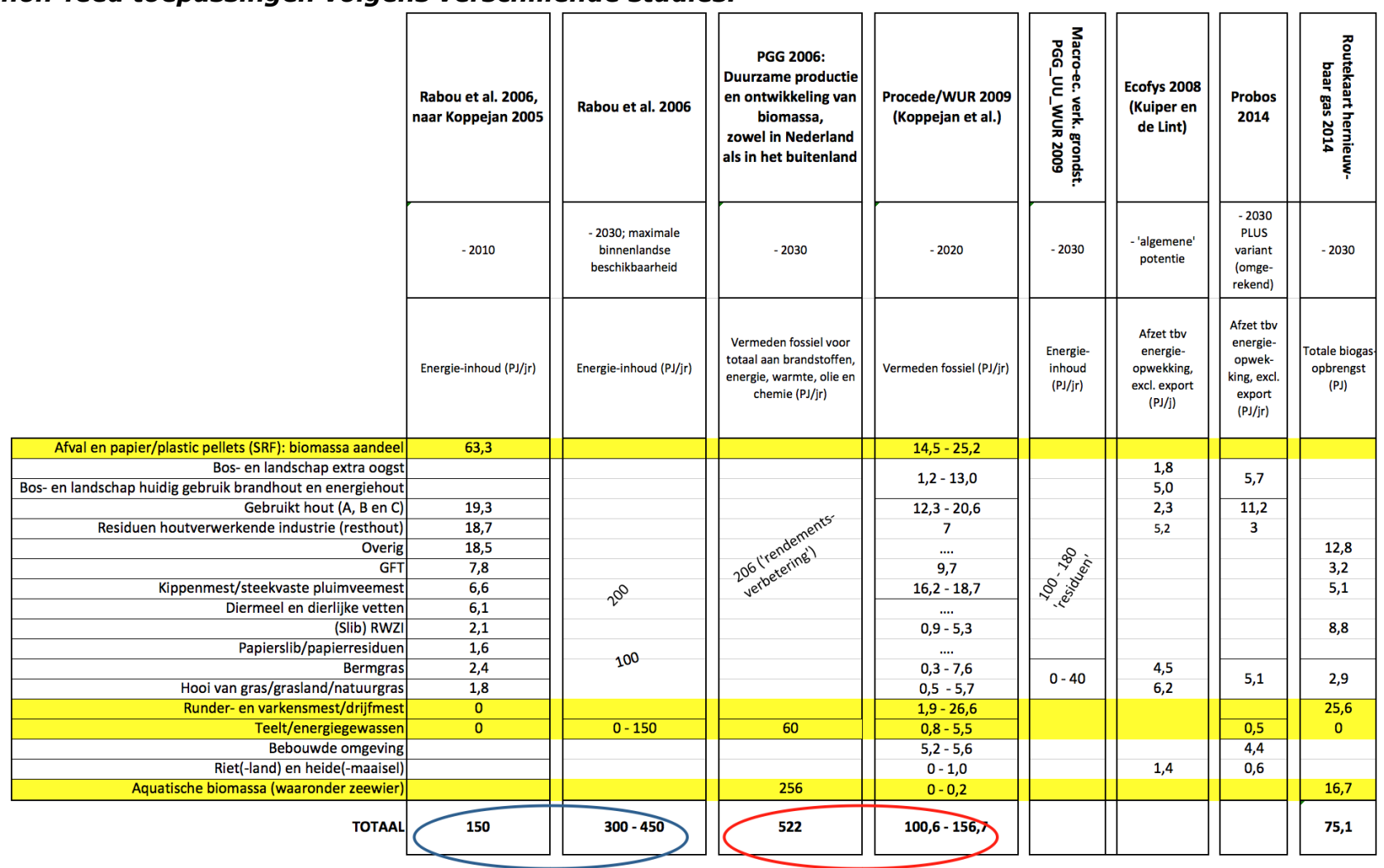

Merk op dat evenals in de huidige situatie (Appendix E) het overgrote deel van de genoemde stromen rest-/recyclestromen betreffen, en dus geen geteelde biomassavraag adresseren.

\footnotetext{
43 J. Ganzevles, Commissie Duurzaamheidsvraagstukken Biomassa: Bijlage 1: Biomassa. Vraag en aanbod in Nederland in 2030. Notitie ten behoeve van Uitwerking Visie Bio-economie 2030 voor de Commissie Corbey, 2014.
} 


\section{Appendix G. Review/suggesties bij Visiedocument Biomassa 2030}

In het Visiedocument wordt ervan uit gegaan dat biomassa, naast andere hernieuwbare bronnen, een belangrijke rol gaat spelen in de energievoorziening op lange termijn. In achterliggende berekeningen (Nationale Energie Verkenning) wordt verwacht dat biobrandstoffen en energieproductie uit biomassa zeer sterk moeten toenemen in de komende jaren. Dat geldt ook voor energieproductie uit wind en zon. Voor de jaren '20 wordt zelfs voorspeld dat biomassa voor energieproductie gedeeltelijk vervangen wordt door zon en wind. Dit project biedt niet de ruimte om te onderzoeken in welke mate de recente ontwikkeling - snelheid waarmee prijzen van energie uit zon en wind dalen - correct zijn meegenomen in die cijfers.

Zoals in eerdere stukken staat (o.a. van de Commissie Corbey) zal biomassa op langere termijn met name een rol moeten spelen bij langeafstand transport, hoogwaardige warmte, en chemie. De rol van biomassa voor laagwaardige warmte, elektriciteit en kortere afstand transport zal afnemen maar wellicht nog niet 0 worden in 2050.

Het is belangrijk dat er geen concurrentiestrijd optreedt tussen fossiel met $\mathrm{CO} 2$ opslag en biomassa (met CO2 opslag). Beiden moeten maximaal benut worden.

"IPCC scenario's laten zien dat biomassa met CO2 opslag nodig is om doelen Parijs akkoord te halen" ${ }^{44}$.

Zelfs bij grootschalige doorbraak van andere duurzame energiebronnen dan biomassa zal grootschalige inzet van biomassa, gecombineerd met $\mathrm{CO} 2$ opslag, noodzakelijk zijn om in de buurt te komen van doelstellingen van Parijs ${ }^{45}$. Grote inspanningen zullen nodig zijn het op een duurzame manier mobiliseren van biomassa voor de bovengenoemde toepassingen en $\mathrm{CO} 2$ opslag.

Het zou goed zijn als het document opmerkt dat planten permanent $\mathrm{CO} 2$ vastleggen dat voor het grootste deel binnen een jaar weer vrij komt als het aan het einde van het groeiseizoen vergaat. Maar een klein deel van de door planten vastgelegde biomassa wordt op een natuurlijke wijze langdurig vastgelegd. Het is belangrijk dat de natuurlijke $\mathrm{CO} 2$ sinks en voorraden (bijvoorbeeld bossen, graslanden in koude gebieden die bodem vormen en venen) in stand worden gehouden en dat de biomassa die geproduceerd wordt zo efficiënt mogelijk benut moet wordt voor voedsel maar ook andere toepassingen. Slechte een fractie van de biomassa die geproduceerd wordt zal gegeten worden. De rest wordt maar gedeeltelijk verbruikt en kan voor een groot deel wel biobased toepassingen gebruikt worden.

\section{Het mobiliseren van de biomassapotentie}

In veel studies zijn schattingen gemaakt van de wereldwijd beschikbare hoeveelheid biomassa die voor biobased toepassingen (energie en chemie) onder bepaalde scenario's beschikbaar komt. Daarin wordt er impliciet van uitgegaan dat technologische ontwikkelingen succesvol zijn en dat er beleid van de grond komt dat die biomassa- ook beschikbaar laat komen.

\footnotetext{
${ }^{44}$ http://bio-based.eu/sustainablefuels/programme?sid=c1133395313340052aef614ed936d0ab

45 IPCC, 2014: Climate Change 2014: Synthesis Report. Contribution of Working Groups I, II and III to the Fifth Assessment Report of the Intergovernmental Panel on Climate Change

Turkenburg, W., S. Schöne, B. Metz \& L. Meyer (2016): De klimaatdoelstelling van Parijs. Wat betekent een maximale temperatuurstijging van "ruim beneden 2 graden, en streven naar anderhalve graad"?, Discussienotitie, https://hier.nu/klimaatbureau/pagina/publicaties (download 25 oktober 2017).
} 


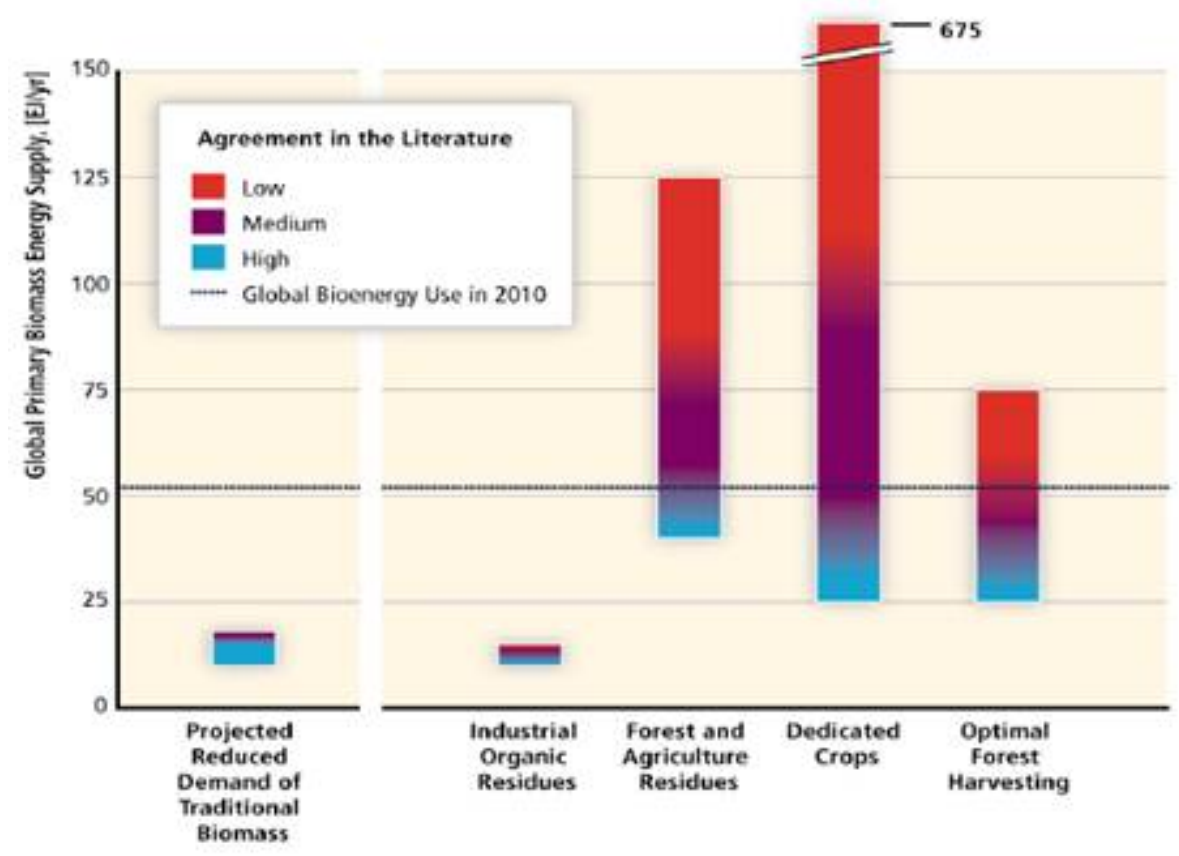

Figuur 3. Samenvatting van consensus over de beschikbaarheid van biomassa voor energie in 2050 in IPCC rapport (2014).

In de scenario's worden bijvoorbeeld impliciet aannames gemaakt over:

- De vleesconsumptie en de hoeveelheid land die daarvoor nodig is of land dat over blijft voor biomassa kan worden gebruikt. Beleid zou hier o.a. gericht moeten worden op productie van efficiënte vleesvervangers, vleesconsumptie duurder maken, shift van koeien naar kippen en varkens.

- Benutting van veld residuen zonder negatieve effecten op bodemkwaliteit: het is nodig om technologie te stimuleren die het maximaal achterlaten nutriënten mogelijk maakt en de afvoer van koolstof optimaliseert (hoeveel koolstof heeft de bodem nodig?).

- Het verschil tussen huidige productie per hectare en potentiele productie per hectare die te benutten is voor productie van biobased grondstoffen - Yield gap benutten voor biobased productie is technisch mogelijk. Vraag is welk beleid er nodig is om dit te bereiken.

- Het benutten van marginaal en gedegradeerd land voor biobased producten. Hier is beleid nodig dat stimuleert dat gewassen voor marginaal land worden ontwikkeld en geproduceerd. Beleid zou zich ook moeten richten op het classificeren van land en zorgen dat op marginaal en kwetsbaar land gewassen geteeld worden die land niet verder degraderen. Juist veel meerjarige biomassagewassen passen hierin.

- Efficiënter benutten van de biomassa: voedselverspilling over de gehele keten verminderen waardoor de facto land voor biobased over blijft; Bioraffinage van biomassa om de verschillende componenten efficiënter in te zetten (eiwitten, vezels, koolhydraten, etc. ).

- Een ander probleem van biomassa is dat het vooral geproduceerd wordt waar het geen directe toepassing heeft. Het is dus nodig om het om te lokaal (via bioraffinage) om zetten in tussenproducten die getransporteerd kunnen worden naar plaatsen waar ze wel efficiënt benut kunnen worden. Het is in het Nederlandse belang dat deze tussenproducten zich tot een beperkt aantal, echte commodities ontwikkelen zodat ze beschikbaar zijn voor de Nederlandse economie. Verschillende artikelen onderstrepen dit (van Dam et al., 2014; Junginger et al 20011; Sanders et al., 2009; Elbersen, 2017)

Dam, J., W. Elbersen, R, Ree. 2014. Setting up international biobased commodity trade chains. A guide and 5 examples in Ukraine. A report for the Netherlands Programmes Sustainable Biomass of Netherlands Enterprise Agency. 
Elbersen, Wolter. 2017. Variable demand as an avenue to sustainable first generation biofuels, In: Sustainable First and Second Generation Bioethanol for Europe: Opportunities for People, Planet and Profit. International conference, 26 September 2017, Brussels. co-hosted by CropEnergies and Nova-Institute.

Sanders, J.P.M., E. Annevelink \& D. van der Hoeven, 2009. The development of biocommodities and the role of North West European ports in biomass chains. Biofpr, May/June isssue, 395-409.

Junginger, Martin, Jinke van Dam, Simonetta Zarrilli, Fatin Ali Mohamed, Didier Marchal, Andre Faaij. 2011. Opportunities and barriers for international bioenergy trade. Energy Policy39(2011)2028-2042. 



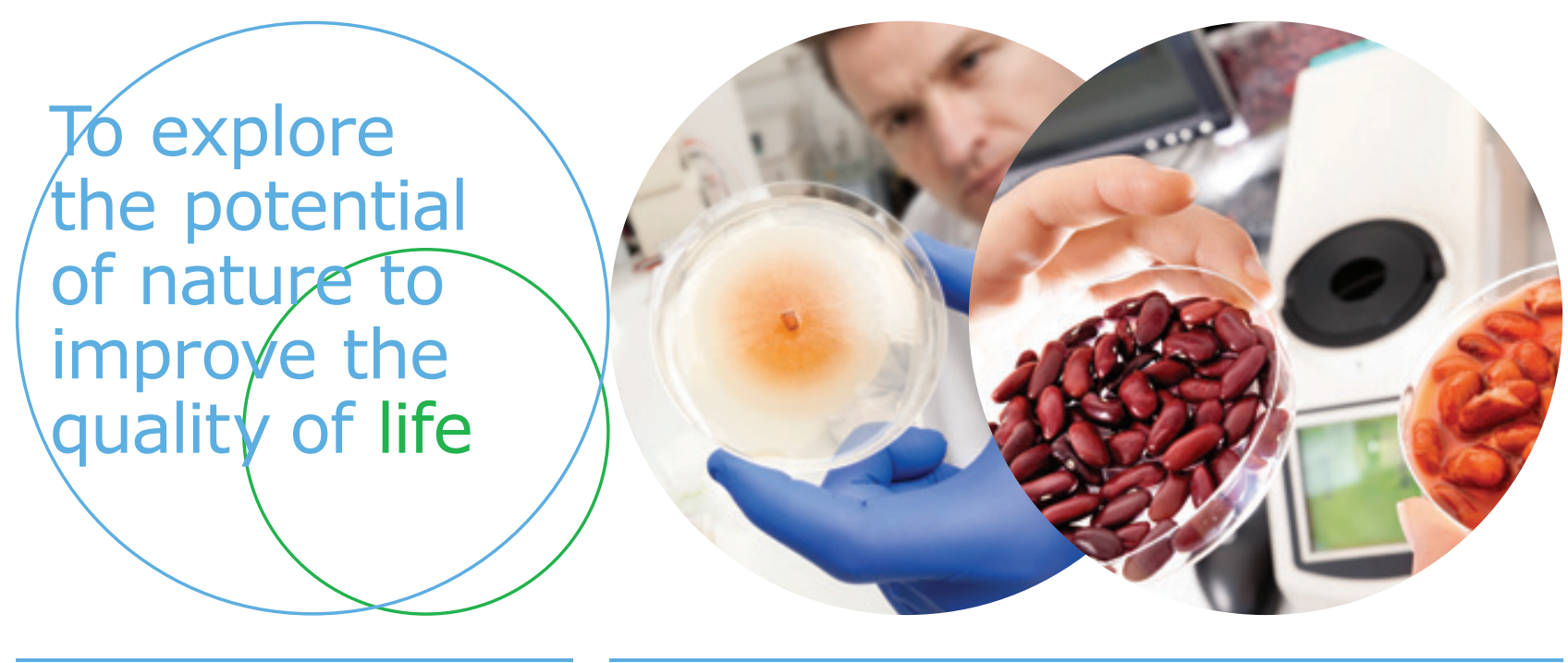

Wageningen Food \& Biobased Research Bornse Weilanden 9

6708 WG Wageningen

www.wur.nl/wfbr

info.wfbr@wur.nl

Rapport 1889
De missie van Wageningen University \& Research is 'To explore the potential of nature to improve the quality of life'. Binnen Wageningen University \& Research bundelen Wageningen University en gespecialiseerde onderzoeksinstituten van Stichting Wageningen Research hun krachten om bij te dragen aan de oplossing van belangrijke vragen in het domein van gezonde voeding en leefomgeving. Met ongeveer 30 vestigingen, 5.000 medewerkers en 10.000 studenten behoort Wageningen University \& Research wereldwijd tot de aansprekende kennisinstellingen binnen haar domein. De integrale benadering van de vraagstukken en de samenwerking tussen verschillende disciplines vormen het hart van de unieke Wageningen aanpak. 